\title{
Molecular Characterization of Salmonella Bacteriophages Isolated From Natural Environment and Its Potential Role in Phage Therapy
}

\author{
Ajit Kumar Ngangbam ${ }^{1}$, Nongmaithem Bijaya Lakshmi Devi ${ }^{2}$ \\ ${ }^{I}$ (Department of Biotechnology, Manipur University, Canchipur, India) \\ ${ }^{2}$ (Faculty of Biology and Environmental Protection, University of Lodz, Poland)
}

\begin{abstract}
Bacteriophages or phages are the viruses that infect bacteria. Phages like all viruses are made up of a nucleic acid core which is surrounded by a protein coat. The majority of phages are known to contain DNA but some contain RNA also. In this study, four salmonella phages were isolated and were subjected to molecular characterization. All the four Salmonella phages were found to contain DNA as their genetic material. Comparison of protein profiles of phages by SDS-PAGE revealed near identical protein profiles for phages $\mathrm{SaP2}$ and SaP4. Study of storage stability of phage indicated that the titer of the Salmonella phage SaP1 almost remains unaltered during the 14 days storage at different temperatures ranging from $-20^{\circ} \mathrm{C}, 4^{\circ} \mathrm{C}$ and $37^{\circ} \mathrm{C}$. This study shows that the isolated phage have good storage stability. The isolated phages also show narrow host range.
\end{abstract}

Keywords: host range, SDS-PAGE, titer, strains

\section{Introduction}

Salmonella phages are believed to play a critical role in Salmonella evolution and to mediate horizontal transfer of virulence genes among Salmonella strains [1] [19] [21]. Salmonella bacteriophages occur naturally in manure and can be isolated for future characterization and potential use as typing reagents, indicators and biocontrol agents. Studies of Salmonella bacteriophages particularly those associated with lysogenic strains, appears to have been undertaken by Burnet [4]. He described four main sub divisions which he designated as phage group A, B, C and D. Later Boyd published his first paper on the temperate bacteriophage isolated from lysogenic strains of $S$. Typhimurium in which he described two main groups of bacteriophages designated as subgroup A and subgroup B[12].

Prior to the discovery and widespread use of antibiotics, it was suggested that bacterial infection could be prevented by the administration of bacteriophage[2]. Twort d'Herelle had suggested for the first time that phages could be used for treating bacterial infections. Report of treating bacterial diseases by applying phages came from France in 1921 for the first time. There have been several reports on phage therapy, but many of these were not scientifically well-demonstrated and later the discovery of antibiotics as chemical agent led to the replacement of phage therapy [15] [10]. The increase in problem of multidrug resistant bacteria made researchers to reconsider use of phages to treat against experimental $E$. coli infections in mice, calves, lambs and piglets [8][9].

With this background, the objectives of the study were Molecular characterization of Salmonella bacteriophages, Storage stability studies of Salmonella bacteriophages and Study of susceptibility of nonSalmonella species to phages isolated in this study.

\section{II.}

\section{Materials And Method}

\subsection{Analysis of bacteriophage nucleic acid}

For extraction of nucleic acid from phage particles, method described by [14] was followed. The phage was precipitated from filtered growth medium with sterile $2 \mathrm{~mol} / \mathrm{ZnCl}_{2}$ at the rate of $1: 50$ for 5 minutes at $37^{\circ} \mathrm{C}$ and pelleted at $4000 \mathrm{rpm}$ for 5 minutes. The pellet was suspended in TENS buffer ( $50 \mathrm{mM}$ Tris pH 8.0, 100 $\mathrm{mM}$ EDTA, $100 \mathrm{mM} \mathrm{NaCl}$ and $0.3 \%$ SDS $)$ and proteinase $\mathrm{k}$ ( $100 \mu \mathrm{g} / \mathrm{ml}$ final concentrations) and incubated at $65{ }^{\circ} \mathrm{C}$ for 10 minutes. Proteins were removed by two extractions with phenol/chloroform/ isoamyl alcohol and DNA was precipitated with isopropanol. After washing in 70\% ethanol, pellets were resuspended in TE $(10 \mathrm{mM}$ Tris $\mathrm{pH} 8.0,1 \mathrm{~m} \mathrm{M/EDTA)} \mathrm{and} \mathrm{analyzed} \mathrm{using} 0.8 \%$ agarose gel electrophoresis.

\subsection{Electrophoresis}

$0.8 \mathrm{~g}$ of agarose (Hi media, Mumbai) was added to $100 \mathrm{ml}$ of $1.0 \mathrm{x}$ TAE buffer and melted. After cooling to $50{ }^{\circ} \mathrm{C}$, Ethidium bromide was added to the agarose solution at the rate of $0.5 \mathrm{mg} / \mathrm{ml}$. The agarose solution was mixed well and poured on a horizontal agarose gel base and allowed to solidify after keeping the 
comb at one side of the gel base. After solidification the comb was slowly removed. The gel was then placed in electrophoresis tank. DNA preparation was then loaded to the wells along with the molecular weight marker and electrophoresis was performed at voltage of 100 millivolt.

\subsection{DNA Molecular weight markers (Bangalore Genei, Bangalore)}

Lambda DNA digested with EcoR1 and Hind III yielding 13 fragments 21226, 5148, 4973, 4277, 3530, 2027, 1904, 1584, 1330, 983, 831, 564, 125 base pairs was used as molecular weight marker.

\subsection{Protein profiles of phage structural proteins}

The protein profiles of phage structural proteins were analysed by Sodium Dodecyl Sulphate Polyacrylamide Gel Electorphoresis (SDS-PAGE) as described by Laemmli (1970). High titer phage suspension $(100 \mu \mathrm{l})$ obtained from confluent lysis plates was taken. After the addition of 5\% $\beta$-mercaptoethanol, samples were boiled for 5 min with equal volume of sample buffer, electrophoresed on $15 \%$ discontinuous gels $(15 \%$ acrylamide, $0.5 \%$ bis-acrylamide) by using the vertical slab gel electrophoresis system (Bangalore Genei, Bangalore) and stained with $0.1 \%$ coomassie blue. Standard molecular weight markers (Bangalore Genei, Bangalore) were run along with the samples to determine molecular weights of sample bands.

\subsection{Preparation of SDS-PAGE apparatus [11]}

Glass plates and glass wares were washed in chromic acid and rinsed in de-ionized water before drying. The spacers were placed in position and edges sealed with $0.5 \%$ agarose solution. The $16.5 \mathrm{~cm}$ wide and $20 \mathrm{~cm}$ high rectangular glass plate was assembled together with the notched plate and the spacers were placed such that the vertical spacers were in contact with the horizontal one at the bottom.

\subsection{Preparation of resolving gel}

Resolving gel mixture was prepared in a small beaker with a magnetic stirrer by mixing the components for a desired concentration of acryl amide according to the following chart [3].

Table- Composition for resolving gels ( $\mathrm{pH}$ 8.8)

\begin{tabular}{|l|l|l|l|l|}
\hline \multirow{2}{*}{ Solution component } & \multicolumn{2}{|c|}{ 12 \% gel } & \multicolumn{2}{c|}{ 15 \% gel } \\
\cline { 2 - 6 } & \multicolumn{2}{|c|}{ Volumes (ml) } & \multicolumn{2}{c|}{ Volumes (ml) } \\
\hline Total volume & 5.0 & 10.0 & 5.0 & 10.0 \\
\hline Deionised water & 1.7 & 3.3 & 1.2 & 2.3 \\
\hline $30 \%$ acrylamide mix & 2.0 & 4.0 & 2.5 & 5.0 \\
\hline $1.5 \mathrm{M}$ Tris-HCl pH 8.8 & 1.3 & 2.5 & 1.3 & 2.5 \\
\hline $10 \%(\mathrm{w} / \mathrm{v})$ SDS & 0.05 & 0.1 & 0.05 & 0.1 \\
\hline $10 \%(\mathrm{w} / \mathrm{v})$ APS & 0.05 & 0.1 & 0.05 & 0.1 \\
\hline TEMED & 0.002 & 0.004 & 0.002 & 0.004 \\
\hline
\end{tabular}

Immediately upon addition of APS followed by TEMED, the solution was poured into the assembled plates and overlaid with iso-butanol to prevent diffusion of oxygen into the gel and for obtaining a uniform margin of the gel. It was allowed to polymerize for about $30 \mathrm{~min}$.

\subsection{Preparation of stacking gel}

In a similar manner, stacking gel mixture with $4 \%$ acrylamide mix was prepared by mixing the components as below [3].

Table- Composition for $4 \%$ stacking gels (pH 6.8)

\begin{tabular}{|l|l|l|}
\hline Solution component & \multicolumn{2}{|c|}{ Volume (ml) } \\
\hline Total volume & 3.0 & 5.0 \\
\hline Deionised water & 1.66 & 2.77 \\
\hline $30 \%$ acrylamide mix & 0.50 & 0.83 \\
\hline $0.5 \mathrm{M}$ Tris $(\mathrm{pH} 6.8)$ & 0.76 & 1.26 \\
\hline $10 \%(\mathrm{w} / \mathrm{v})$ SDS & 0.05 & 0.05 \\
\hline $10 \%(\mathrm{w} / \mathrm{v})$ APS & 0.05 & 0.05 \\
\hline TEMED & 0.005 & 0.005 \\
\hline
\end{tabular}




\subsection{Storage stability studies of Salmonella bacteriophages}

The effect of different temperatures on the viability of Salmonella phages during storage was studied. The phage was prepared in large scale using soft agar overlay method and harvested with phage buffer at $10^{12}$ $\mathrm{pfu} / \mathrm{ml}$ concentration. $100 \mathrm{ml}$ of phage was distributed to each storage bottle containing $10 \mathrm{ppm}$ chloroform and stored at $-20{ }^{\circ} \mathrm{C}, 4^{\circ} \mathrm{C}$, and $37^{\circ} \mathrm{C}$ for 14 days. Periodically the titer was measured.

\subsection{Study of susceptibility of non-Salmonella species to phages isolated in this study}

To know the susceptibility of Salmonella phages to other non-Salmonella species, susceptibility study of non-Salmonella species to phages isolated in this study was conducted. The host range of phages outside Salmonella group was studied using Escherichia coli, Staphylococcus aureus, and Vibrio harveyi.

\subsection{Analysis of phage nucleic acid}

\section{Results}

The DNA of phages were isolated and analyzed by agarose gel electrophoresis. DNA bands corresponding to about $20 \mathrm{~kb}$ (Fig. 1) were visible after electrophoresis indicating that the phages contained DNA as their genetic material.

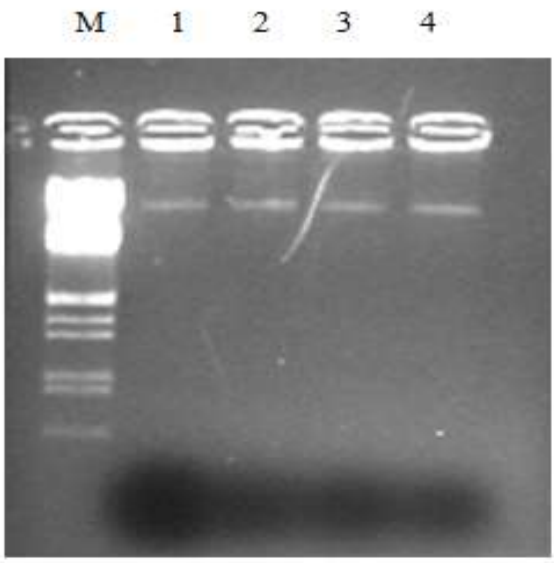

Lane M: Marker- ג DNA Eco RI/ HindIII

Lane 1: SaP1 phage

Lane 2: SaP2 phage

Lane 3: $\mathrm{SaP} 3$ phage

Lane 4: SaP4 phage

Fig.1. Agarose gel electrophoresis of DNA extracted from different Salmonella phages

\subsection{Protein profile of the phages}

All the four Salmonella phages which were distinguishable by morphology were further characterized by SDS-PAGE analysis of structural proteins. All the four isolated Salmonella phages show different banding pattern with some main structural proteins as well as several minor proteins (Fig. 2). In SaP1 phage, major 36 $\mathrm{kDa}$ and $33 \mathrm{kDa}$ structural proteins and $56 \mathrm{kDa}, 53 \mathrm{kDa}, 48 \mathrm{kDa}, 45 \mathrm{kDa}, 40 \mathrm{kDa}$ and $27 \mathrm{kDa}$ minor proteins were detected. In SaP2 phage, major $56 \mathrm{kDa}, 52 \mathrm{kDa}, 48 \mathrm{kDa}, 36 \mathrm{kDa}$ and $33 \mathrm{kDa}$ structural proteins and 54 $\mathrm{kDa}, 39 \mathrm{kDa}, 30 \mathrm{kDa}$ and $27 \mathrm{kDa}$ minor proteins were detected. In SaP3 phage, major $52 \mathrm{kDa}$ structural proteins and $48 \mathrm{kDa}, 45 \mathrm{kDa}, 37 \mathrm{kDa}$ and $28 \mathrm{kDa}$ minor proteins were detected. In SaP4 phage, major $54 \mathrm{kDa}, 50 \mathrm{kDa}$, $43 \mathrm{kDa}, 36 \mathrm{kDa}, 32 \mathrm{kDa}$ structural proteins and $68 \mathrm{kDa}, 61 \mathrm{kDa}, 46 \mathrm{kDa}, 29 \mathrm{kDa}, 27 \mathrm{kDa}$ and $24 \mathrm{kDa}$ minor proteins were detected. The molecular weights of phage structural proteins are given in Table 1. 

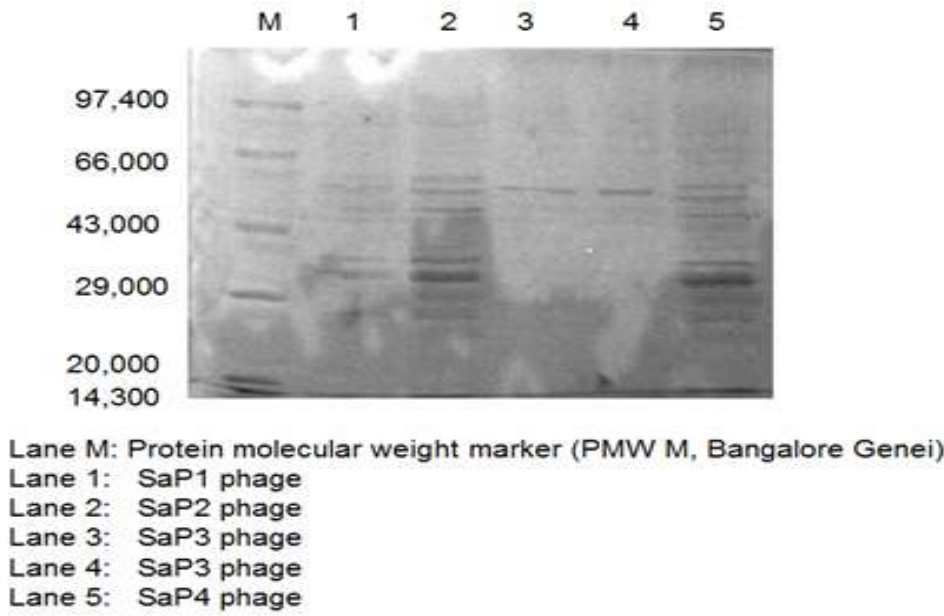

Fig. 2. SDS-PAGE of bacteriophage structural protein

Table-1. Molecular weight of phage structural proteins

\begin{tabular}{|l|l|l|}
\hline Phage isolate & $\begin{array}{l}\text { Mol. Weight (kDa) of major } \\
\text { proteins }\end{array}$ & $\begin{array}{l}\text { Mol. Weight (kDa) of minor } \\
\text { proteins }\end{array}$ \\
\hline $\mathrm{SaP} 1$ & 36 and 33 & $56,53,48,45,40$ and 27 \\
\hline $\mathrm{SaP} 2$ & $56,52,48,36$ and 33 & $54,39,30$ and 27 \\
\hline $\mathrm{SaP} 3$ & 52 & $48,45,37$ and 28 \\
\hline $\mathrm{SaP} 4$ & $54,50,43,36$ and 32 & $68,61,46,29,27$ and 24 \\
\hline
\end{tabular}

\subsection{Storage stability of Salmonella phage}

The storage stability of phages was tested by storing phage preparations at $37^{\circ} \mathrm{C}, 4^{\circ} \mathrm{C}$, and $-20^{\circ} \mathrm{C}$ and estimating the titer values at 1,7 and 14 days. The results of storage stability studies are given in Table 2 . A test for lytic activity of SaP1 phage revealed that $\mathrm{SaP} 1$ phage retained its lytic activity at all temperature of storage even after 14 days. The titer of $\mathrm{SaP} 1$ phage was almost unaltered during 14 days of storage at $37^{\circ} \mathrm{C}, 4^{\circ} \mathrm{C}$, and $20^{\circ} \mathrm{C}$.

Table- 2. Titer values of SaP1 phage at different storage temperatures

\begin{tabular}{|l|l|l|l|}
\hline \multirow{2}{*}{$\begin{array}{c}\text { Length of storage in } \\
\text { days }\end{array}$} & \multicolumn{3}{|c|}{ pfu/ml of phage at different temperature } \\
\cline { 2 - 4 } & $\mathbf{- 2 0}{ }^{\mathbf{}} \mathbf{C}$ & $\mathbf{4}^{\mathbf{}} \mathbf{C}$ & $\mathbf{3 7}{ }^{\circ} \mathbf{C}$ \\
\hline 1 & $2.8 \times 10^{12}$ & $2.7 \times 10^{12}$ & $2.7 \times 10^{11}$ \\
\hline 7 & $2.6 \times 10^{12}$ & $2.5 \times 10^{12}$ & $2.5 \times 10^{11}$ \\
\hline 14 & $2.6 \times 10^{12}$ & $2.5 \times 10^{12}$ & $2.4 \times 10^{11}$ \\
\hline
\end{tabular}

\subsection{Study of susceptibility of non-Salmonella species to phages isolated in this study}

The host range of phages outside Salmonella group was studied using E. coli, S. aureus, and V. harveyi. All the four Salmonella phages isolated in this study did not lyse any of the non-Salmonella strains used demonstrating that the phages are highly specific to Salmonella spp (Table 3).

Table- 3. Susceptibility of non-Salmonella species to Salmonella Phages

\begin{tabular}{|l|l|l|l|l|l|}
\hline \multirow{2}{*}{$\begin{array}{l}\text { Bacterial } \\
\text { species } \\
\text { tested }\end{array}$} & \multirow{2}{*}{$\begin{array}{l}\text { No. of strains } \\
\text { tested }\end{array}$} & \multicolumn{4}{|c|}{ No. susceptible to phages } \\
\cline { 3 - 6 } & & SaP1 & SaP2 & SaP3 & SaP4 \\
\hline V. harveyi & 3 & 0 & 0 & 0 & 0 \\
\hline S. aureus & 3 & 0 & 0 & 0 & 0 \\
\hline E. coli & 1 & 0 & 0 & 0 & 0 \\
\hline
\end{tabular}




\section{Discussion}

The emergence of multidrug resistant bacteria has opened a window of opportunity for phage therapy. Modern innovations combined with careful scientific methodology can enhance the ability of mankind to make it work. The potential unique advantage of phage treatment over chemotherapy is the narrow host range of phages and it does not harm the normal intestinal microflora (Carlton, 1999). The DNA of phages were isolated and analyzed by agarose gel electrophoresis. DNA bands corresponding to about $20 \mathrm{~kb}$ (Fig. 1) were visible after electrophoresis indicating that the phages contained DNA as their genetic material. There were reports of various Salmonella phages having DNA as their genetic material. Salmonella bacteriophage P22 is an unassigned species of temperate bacteriophage in the family Podoviridae that infects Salmonella species. The genome consists of double-stranded DNA, terminally redundant, and circularly permuted (Schmeiger, 1982). The structural proteins of all the four isolated Salmonella phages were analyzed by SDS-PAGE. Both major structural proteins and several minor proteins were found in the isolated phage. The Salmonella phages SaP2 and SaP4 were showing slightly similar banding pattern. The sizes of major protein bands in all the four Salmonella phages were as follows; In SaP1 phage $36 \mathrm{kDa}$ and $33 \mathrm{kDa}$ major proteins were detected. In SaP2 phage $56 \mathrm{kDa}, 52 \mathrm{kDa}, 48 \mathrm{kDa}, 36 \mathrm{kDa}$ and $33 \mathrm{kDa}$ major proteins were detected. In SaP3 phage, only one major protein was detected i.e. $52 \mathrm{kDa}$ and in SaP4 phage $54 \mathrm{kDa}, 50 \mathrm{kDa}, 43 \mathrm{kDa}$, $36 \mathrm{kDa}$ and $32 \mathrm{kDa}$ major protein were detected. The observed difference in the protein profile could be responsible for difference in host range and plaque morphology of the phages. Similar results have been reported previously using T even phages of Escherichia coli [13].

Even though the phage belongs to the same family, the structural proteins are unique to each phage and depend on their morphotype. It was suggested that the protein pattern could be used for phage morphotype, characterization and differentiation [17].

When the phages are produced in large quantity for its application, it is necessary to store them in optimum condition such as temperature, $\mathrm{pH}$ and salt concentration. In this study, the titer of the Salmonella phage SaP1 almost remains unaltered during the 14 days storage at different temperatures ranging from $-20^{\circ} \mathrm{C}, 4^{\circ} \mathrm{C}$ and $37^{\circ} \mathrm{C}$. This study showed the stability of SaP1 phage while storing at different temperature. [16] had earlier reported that some phages might be inactivated at higher temperature. All the four isolated Salmonella phages isolated in this study did not lyse any of the non-Salmonella strains used demonstrating that the phages are highly specific to Salmonella spp (Table 3). This study also supported the fact that the host range of phages is narrow, i.e., they do not cross their generic boundaries [6]. This has been documented from studies of more than 4000 bacteriophage isolates described at that time.

\section{References}

[1] A.J. Baumler, The record of horizontal gene transfer in Salmonella, Trends Microbiol, 5, 1997, 318-322.

[2] A . Sulakvelidze, Z. Alavidze and J.G.J. Morris. Bacteriophage therapy, Antimicrob. Agents Chemother, 45, 2001, 645-659.

[3] E. Harlow and D. Lane, Antibodies: a laboratory manual, (Cold Spring Harbor Laboratory Press, New York, 1998$) 736$.

[4] F.M. Burnet, Bacteriophage activity and the antigenic structure of bacteria, J. Pathol, 33, Bacteriol 1930, 647-664.

[5] F.W. Twort, An investigation on the nature of ultramicroscopic viruses, Lance, 11, $t$ 1915, 1241.

[6] H.W. Ackermann, M.S. Dubow. Viruses of Prokaryotes, in, General Properties of Bacteriophages (Vol. I. CRC Press, Boca Raton. 1987).

[7] H. Schmieger, Packaging signals for phage P22 on the chromosome of Salmonella typhimurium. Mol. Gen. Genet, 187(3), 1982, $516-518$.

[8] H.W. Smith and M B. Huggins, Successful treatment of experimental Escherichia coli infections in mice using phage: its general superiority over antibiotics, J. Gen. Microbiol, 128, 1982, 307-318.

[9] H.W. Smith, M B. Huggins and K.M. Shaw, Factors influencing the survival and multiplication of bacteriophages in claves and in their environment, J. Gen. Microbiol,133, 1987, 1127-1135.

[10] J. Alisky, K. Iczkowski, A. Rapoport and N. Troitsky Bacteriophages show promise as antimicrobial agents, J. Infect, 36, 1998, 515.

[11] J. Sambrook, E.F. Fritsch and T. Maniatis, Molecular cloning: a laborator manual, (2 ${ }^{\text {nd }}$ ed. Cold Spring Harbor Laboratory Press, N.Y. 1989)

[12] J.S.K. Boyd, The symbiotic bacteriophages of Salmonella typhimurium. J. Pathol. Bacteriol, 62, $1950,501-517$.

[13] K. Hantke, Major outer membrane protein of Escherichia coli k12 serve as receptors for the phage T2 ( protein 1a) and 434 ( protein 1b), Mol. Gen. Genetics, 164, 1978, 131-135.

[14] M.T. Su, T.V. Venkatesh and R. Bodmer, Large and small-scale preparation of bacteriophage $\lambda$ lysate and DNA, BioTechniques, 25, 1998, 44-46.

[15] P.A. Barrow and J.S. Soothi, Bacteriophage therapy and prophylaxis: rediscovery and renewed assessment of potential, Trends. Microbiol , 5, 1997 268-271.

[16] P. Rossi and M. Arageno, Analysis of bacteriophage inactivation and its attenuation by adsorption onto colloidal particles by bath agitation technique. Can. J. Microbiol,45, 1999, 9-17.

[17] R. Barangou, S.S. Yoon, F. Breidt, T.R. Klaenhammer and H.P. Fleming, Identification and characterization of Leuconostoc fallax strains isolated from industrial sauerkraut fermentation, Appl. Environ. Microbiol, 68, 2002, 2877-2844.

[18] R.M. Carlton, Review: Phage Therapy: Past History and Future Prospects, Archivum Immunologiae et Therapiae Experimentalis, 47, 1999, 267-274.

[19] S. Porwollik, Mcclell and M. Lateral gene transfer in Salmonella. Microbes Infect, 5, 2003, 977-989.

[20] U.K. Laemmli, Cleavage of structural proteins during the assembly of the head of bacteriophage of T4. Nature (London),227, 1970, 680-685.

[21] W. Rabsch, S. Mirold, W.D. Hardt and H. Tschape, The dual role of wild phages for horizontal gene transfer among Salmonella strains. Berl Muench. Tieraerztl. Wosenschr, 115, 2002, 355-359. 